\title{
GYERMEKKORI ELHÍZÁS ELŐFORDULÁSA MAGYARORSZÁGON (COSI)
}

\section{CHILDHOOD OBESITY PREVALENCE IN HUNGARY (COSI)}

\author{
Kovács Viktória Anna', Erdei Gergő² \\ 'PhD, táplálkozástudományi szakreferens, Országos Gyógyszerészeti és Élelmezésegészzégügyi Intézet, Budapest \\ kovacs.viktoria@ogyei.gov.hu \\ ²dietetikus, Országos Gyógyszerészeti és Élelmezésegészségügyi Intézet, Budapest \\ erdei.gergo@ogyei.gov.hu
}

\begin{abstract}
ÖSSZEFOGLALÁS
Magyarországon a védőnők kétévente mérik a tanulók testsúlyát és testmagasságát az ún. index osztályokban, melyek a 26/1997. (IX. 3.) NM rendelet szerint a páros évfolyamú osztályok. Az iskola-egészségügyi szűréseken kiszűrt tanulók esetében a túlsúly vagy az elhízás diagnózisát a házi gyermekorvos vagy az iskolaorvos állítja fel. Ezzel párhuzamosan, a tanulók fizikai állapotának és edzettségének mérése céljából 2015-ben indult útjára a NETFIT, ami szintén minden iskolában kötelező az ötödik évfolyamtól kezdődően.

Az Egészségügyi Világszervezet Gyermekkori Tápláltsági Állapot Felmérése (WHO COSI) 2007-ben indult. Ennek keretében Magyarországon eddig két alkalommal történt adatgyűjtés, 2010-ben és 2016-ban, első és második osztályos tanulók körében. Az országos reprezentatív minta kialakítása kétlépcsős csoportos mintavétellel történt. Összesen 5332 tanuló (48,4\% fiú; átlagéletkor 7,54 $\pm 0,64$ év) testsúlyát és testmagasságát mértük meg 2016-ban. A túlsúly és az elhízás prevalenciáját mindhárom érvényben lévő módszer szerint számoltuk (WHO, IOTF és hazai határértékek). Az IOTF-definíció szerint a túlsúly és elhízás együttes előfordulási aránya 2016-ban 22,5\% volt, míg a WHO-definíciót alkalmazva 28,5\%. Hazai határértékek szerint az előfordulási arány 20,9\%. A 2010-es és 2016-os adatok viszonylagos stabilitást mutattak az előfordulási arányban. 2016-ban régiós és településnagyság szerint is vizsgáltuk az adatainkat, és jelentős különbségeket találtunk az egyes régiók között. Mind a túlsúly (beleértve az elhízottakat is), mind az elhízás aránya a Dél-Dunántúli régióban volt a legmagasabb (27,2\%; 12,0\%), és Közép-Magyarországon (18,1\%; 6,1\%), valamint Nyugat-Dunántúlon volt a legalacsonyabb $(20,4 \% ; 8,4 \%)$. Az elhízás előfordulását nézve kétszeres volt a különbség a legmagasabb és a legalacsonyabb előfordulású területek kötött (12\% vs. 6,1\%). Településnagyság szerinti bontásban nem láttunk szignifikáns különbséget az előfordulási arányokban.
\end{abstract}

\section{ABSTRACT}

In Hungary there is a long-standing history of school health examination carried out annually by school nurses in the $2^{\text {th }}, 4^{\text {th }}, 6^{\text {th }}, 8^{\text {th }}, 10^{\text {th }}$ and $12^{\text {th }}$ grades (i.e. at ages of $8,10,12,14,16$ and 18 years). These health check-ups are mandatory and regulated by law. Within the procedure school nurses measure, among others, body height and body weight to identify overweight and 
obese children. In parallel, the NETFIT system was introduced in 2015 with the aim of objectively measure and monitor weight and fitness status of children from the $5^{\text {th }}$ grade (i.e. in 10-18 years). These tests are also compulsory.

Hungary joined the WHO Childhood Obesity Surveillance Initiative (COSI) in 2007, and so far collected the data two times, in the $2^{\text {nd }}$ (in 2010) and $4^{\text {th }}$ rounds (in 2016). The target population for Hungary in both rounds was defined as children aged 7.0-7.9 years. National representative sample was generated by two-stage cluster sampling and a total of 5,332 children ( $48.4 \%$ boys; age $7.54 \pm 0.64$ years) were measured (weight and height) in October 2016. Population estimates were calculated using the WHO, IOTF and national cut-offs. In 2016, 22.5\% of children were identified as overweight or obese according to the IOTF classification, compared with $28.4 \%$ according to the $\mathrm{WHO}$ definition. Using the national criteria, prevalence rate for overweight and obesity was 20.9\%. Between 2010 and 2016, each classification indicated possible stability in overweight and obesity prevalence. No significant gender difference was observed in the progress. In the $4^{\text {th }}$ round we also studied geographical distribution and urban-rural differences. We obtained significant differences in the prevalence rates of overweight and obesity among the seven Hungarian geographic regions. Both overweight (including obesity) and obesity were most frequent in Southern Transdanubia (27.2\%; 12.0\%) while the lowest rates were found in Central Hungary (18.1\%; 6.1\%) and in Western Transdanubia (20.4\%; 8.4\%). The obesity prevalence in the region with the highest rate was two times higher than in the one with the lowest rate (12\% vs. $6.1 \%)$. Urban-rural differences were not substantial.

Kulcsszavak: testtömegindex, gyermekek, túlsúly, elhízás, prevalencia

Keywords: body mass index, children, overweight, obesity, prevalence

\section{BEVEZETÉS}

A gyermekkori elhízás a 21. század egyik legsúlyosabb népegészségügyi kihívása (Dietz, 2004), melynek prevalenciája riasztó ütemben nő, veszélyeztetve ezzel az ellátó rendszerek fenntarthatóságát (Sonntag et al., 2016). Míg a túlsúlyos gyermekek (0 és 5 év között) száma világszerte 1990-ben 32 millió volt, 2016ban már 41 millióra nőtt, ami négyszerese Magyarország lakosságának (URL1). Amennyiben a jelenlegi trenden nem változtatunk, 2025-re a túlsúlyos és elhízott gyermekek száma világszerte megközelíti majd a 70 milliót (URL1).

A gyermekkori túlsúly és elhízás aláássa a fizikai, szociális és pszichológiai jóllétet, és ismert kockázati tényezője a felnőttkori elhízásnak, valamint számos krónikus, nem fertőző megbetegedésnek (URL2). Emellett gyakoribbak az ortopédiai problémák, a szorongás és a depresszió, valamint a túlsúlyos gyerekek fele, a túlsúlyos serdülők 80\%-a felnőttkorban is elhízott marad (URL3). Fontos tudni azonban, hogy amennyiben a túlsúlyos gyermek testsúlya rendeződik, a jövőben akkor is nagyobb esélye lesz a felnőttkori szív- és érrendszeri betegségekre, mint egy normál súlyú gyermeknek (Bridger, 2009). 
Ahhoz, hogy célzott beavatkozásokat tervezhessünk, illetve hogy monitorozni tudjuk az egyes intervenciók hatékonyságát, jó minőségü, összehasonlítható adatokra van szükségünk.

\section{ORSZÁGOS, MÉRÉSEN ALAPULÓ TÁPLÁLTSÁGIÁLLAPOT-FELMÉRÉSEK MAGYARORSZÁGON}

Hazánkban jelenleg több, jogszabályok által elöírt adatgyüjtés folyik a gyermekek tápláltsági állapotáról. A legrégebbiek az iskola-egészségügyi szürések keretében végzett testsúly- és testmagasságmérések. Ezek a vizsgálatok a 26/1997. (IX. 3.) NM rendelet szerint jelenleg a 2., 4., 6., 8., 10. és 12. évfolyamokban történnek iskolavédőnők által. A diagnózis felállítása a mért adatok alapján az iskolaorvos vagy a háziorvos feladata. A túlsúly és az elhízás megállapítása a 2003ban kiadott Útmutató és táblázatok a gyermekkori tápláltság megitéléséhez címü módszertani levél szerint történik (Ágfalvi et al., 2004). Az útmutató az Országos Longitudinális Gyermeknövekedés-vizsgálat adatai alapján készült (Joubert et al., 2006). Túlsúlyosnak tekinti azokat a a gyermekeket, akiknek a testmagasságra vonatkoztatott testtömeg percentilise a 90 percentilis fölötti értékzónába esik.

Az iskola-egészségügyi szürések rendszerével párhuzamosan 2015-ben került bevezetésre a Nemzeti Egységes Tanulói Fittségi Teszt (NETFIT), amelynek célja a tanulók fizikai állapotának és edzettségének (fizikai fittségének) mérése. A mérések a 20/2012. (VIII. 31.) EMMI rendeletben meghatározott, országosan egységes módszertant követnek, és egységes eszközöket használnak. A méréseket a testnevelő tanárok végzik, és az adatokat egy erre létrehozott informatikai rendszerbe töltik fel. Az adatok elemzése központilag, a Magyar Diáksport Szövetség szakértôi által történik. A túlsúly és az elhízás meghatározásához az International Obesity Task Force (IOTF) által javasolt definíciót használják (Cole-Lobstein, 2012).

\section{WHO GYERMEKKORI TÁPLÁLTSÁGI ÁLLAPOT FELMÉRÉS (COSI)}

Az európai régióban összehasonlítható módon a gyermekkori túlsúly és elhízás előfordulását az Egészségügyi Világszervezet (WHO) Gyermekkori Tápláltsági Állapot Felmérés (WHO Childhood Obesity Surveillance Initiative, WHO COSI) nézi (Wijnhoven et al., 2013). A vizsgálat, mely kétévente gyüjt mért adatokat, 2007 óta zajlik, ma már több mint negyven ország részvételével. A részt vevő országok azonos protokoll alapján, ugyanolyan mérőmüszerekkel és definíció szerint határozzák meg a túlsúly és elhízás előfordulását 6-9 éves gyermekek körében.

Hazánkban eddig két alkalommal történt adatgyüjtés a COSI keretében, 2010ben és 2016-ban. A felmérés során iskolavédőnők közremüködésével testmagas- 
ság- és testsúlymérés történik. Az egységes mérőmüszereket 2010-ben a koordináló intézet, 2016-ban a NETFIT eszközparkja biztosította. Az adatgyüjtés országos reprezentatív mintán történik. Hazánkban a célpopuláció minden esetben a 7,0-7,9 évesek.

A WHO ajánlása szerint korcsoportonként 2800 gyermeket kell beválasztani. Mivel a mi felmérésünk egyetlen korcsoportot érint, ez a 2800 fö az elérni kívánt mintanagyság. A WHO a tényleges (meghiúsulásokat is tartalmazó, tehát kiindulási) mintanagysággal kapcsolatban az országok saját tapasztalataira bízza annak megadását. A korábbi tapasztalatok alapján kb. 10\%-os meghiúsulási aránnyal számolva határoztuk meg 3100 fóben a kiindulási mintanagyságot. Az Oktatási Hivatal adatbázisa szerint az átlagos osztályonkénti tanulólétszám húsz fő az első és második évfolyamokon, tehát kb. 155 iskolát és ugyanennyi elsős és másodikos osztályt választunk minden alkalommal kétlépcsős, csoportos mintavétellel. Ebből a mintából a 2016-os vizsgálatban végül 136 intézmény vett részt (1. ábra).

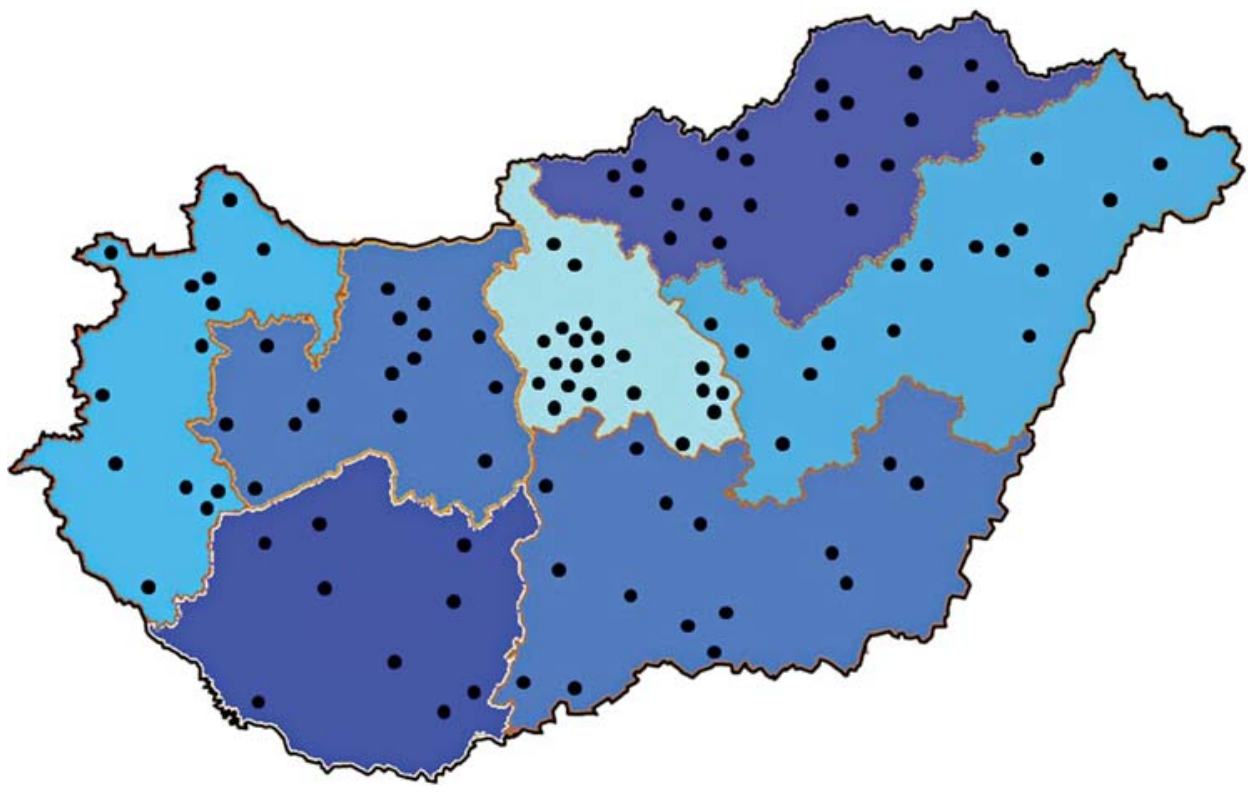

1. ábra. A COSI-vizsgálatban 2016-ban részt vevő 136 iskola földrajzi eloszlása. Minden pont 1-1 részt vevő általános iskolát jelöl.

Az összehasonlíthatóság miatt a túlsúly és elhízás meghatározásához többféle módszert követünk. Az 1. táblázat áttekinti az általunk a COSI-ban használt definíciókat. 
1. táblázat. A normál, a túlsúlyos és az elhízott tápláltsági állapotok besorolásának WHO-, IOTF- és magyar definíciók szerinti határértékei

\begin{tabular}{|l|c|c|c|}
\hline & WHO & IOTF & Magyar \\
\hline Normál & $\geq-1$ SD és $\leq 1 \mathrm{SD}$ & $\geq 18,5$ és $<25$ & $\geq$ P10 és $<$ P90 \\
Túlsúlyos & $>1$ SD és $\leq 2 \mathrm{SD}$ & $\geq 25$ és $<30$ & $\geq$ P90 és $\leq$ P97 \\
Elhízott & $>2 \mathrm{SD}$ & $\geq 30$ & $>$ P97 \\
\hline
\end{tabular}

SD: standard deviáció, P: percentilis

Cole-Lobstein, 2012; de Onis et al., 2007; Joubert et al., 2006 alapján saját szerkesztés

Jól látszik, hogy a gyermekkori elhízás definíciója jelenleg nem egységes. Ez sajnos nagyban megnehezíti a különböző vizsgálatokból kikerült adatok összehasonlítását, mind hazai, mind nemzetközi vonatkozásban. Emellett nehéz tendenciákról beszélni akkor, ha különböző definíciók szerint nyert prevalenciákat hasonlítunk össze. Hogy érzékeltessük a határértékek közötti különbséget, a $2 a, b$ ábra bemutatja hétéves fiúknál és lányoknál a túlsúly és elhízás diagnózisának felállításához használt BMI-értékeket három, Európában futó vizsgálatban használt definíció alapján (Kovács et al., 2018).

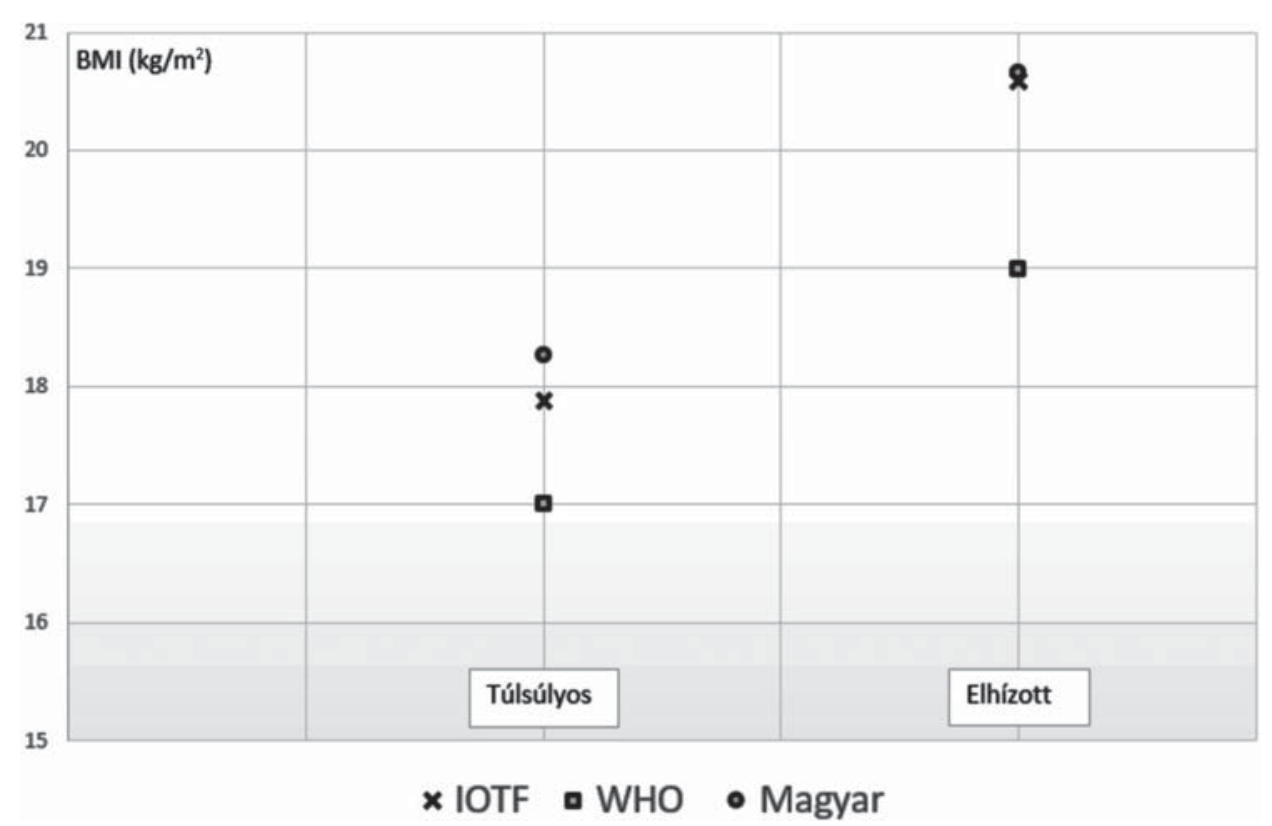

2a ábra. A túlsúly és az elhízás vonatkozásában, 7 éves fiúknál használt testtömegindex (BMI) -határértékek összehasonlítása a WHO-, az IOTF- és a magyar definíciók szerint. Saját szerkesztés 


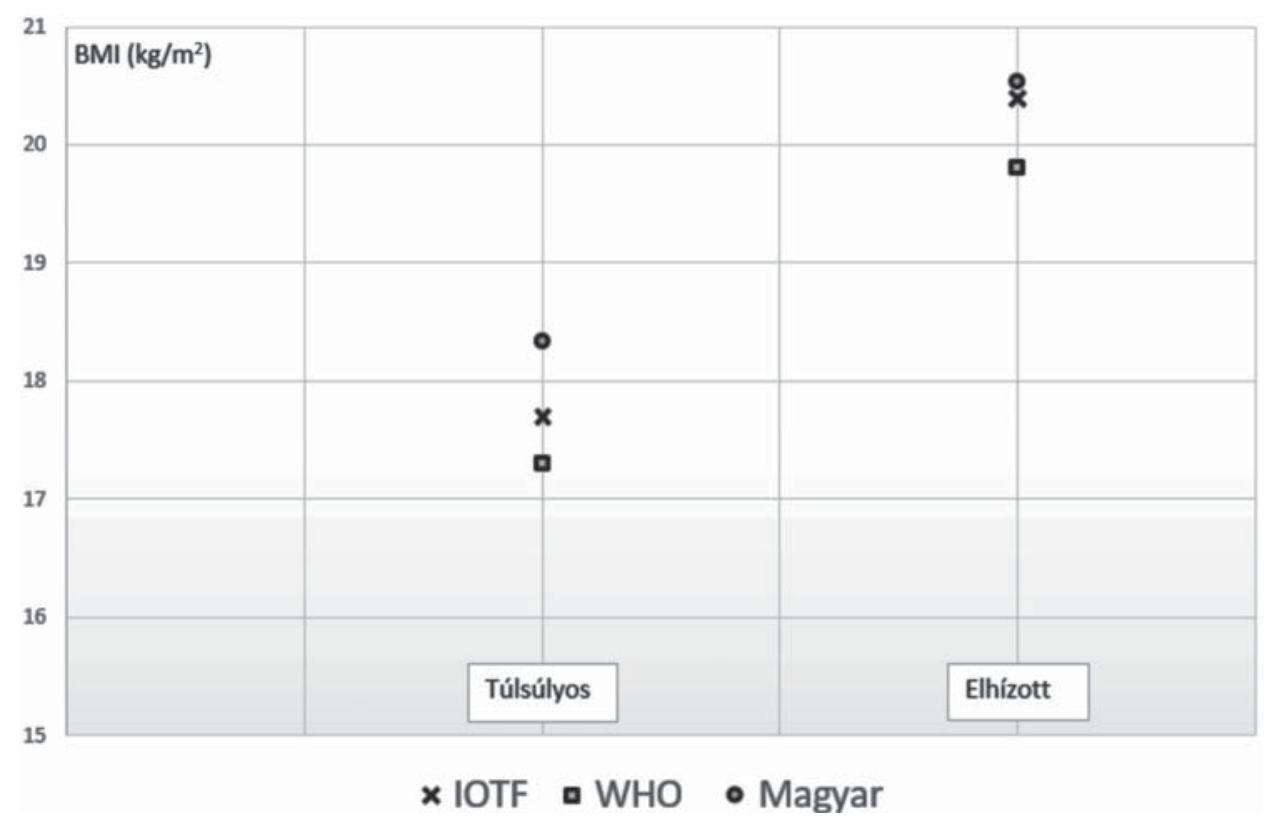

2b ábra. A túlsúly és az elhízás vonatkozásában, 7 éves lányoknál használt testtömegindex (BMI) határértékek összehasonlítása a WHO, az IOTF és a magyar definíciók szerint.

Saját szerkesztés

Az ábrákon jól látható, hogy mindkét nemnél mind a túlsúly, mind az elhízás vonatkozásában a WHO-definíciónál a legalacsonyabb a határérték. Így, ha ezt a módszert választjuk, akkor kapjuk ugyanazon adatbázison a legmagasabb prevalencia értékeket. Ezért fontos, hogy mindig azonos módszerrel számolt előfordulási arányokat hasonlítsunk össze.

A COSI-vizsgálatban az összehasonlíthatóság miatt mindhárom módszerrel kiszámoltuk az előfordulási arányokat. A fentiek tükrében nem meglepő, hogy jelentős különbségeket találtunk. Az IOTF-definíció szerint a túlsúly és az elhízás együttes előfordulási aránya 2016-ban 22,5\% volt, míg a WHO-definíciót alkalmazva 28,5\%. Hazai határértékek szerint az előfordulási arány $20,9 \%$ volt (2. táblázat).

2016-ban régiós és településnagyság szerint is vizsgáltuk adatainkat, és jelentős különbségeket találtunk az egyes régiók között (Erdei et al., 2018). Mind a túlsúly (beleértve az elhízottakat is), mind az elhízás aránya a Dél-Dunántúli régióban volt a legmagasabb $(27,2 \% ; 12,0 \%)$, és Közép-Magyarországon (18,1\%; 6,1\%), valamint Nyugat-Dunántúlon volt a legalacsonyabb (20,4\%; 8,4\%) (3. ábra). Az elhízás előfodulását nézve kétszeres volt a különbség a legmagasabb és a legalacsonyabb elöfordulású területek kötött ( $12 \%$ vs. 6,1\%). Településnagyság szerinti bontásban nem láttunk szignifikáns különbséget az előfordulási arányokban. 
2. táblázat. A túlsúly és az elhízás előfordulása 7 évesek körében 2016-ban különböző definíciók szerint számolva (populációs becslésen alapulva)

\begin{tabular}{|c|c|c|c|c|}
\hline & $\begin{array}{l}\text { Összesen } \\
\% \\
(95 \% \text { CI })\end{array}$ & $\begin{array}{l}\text { Lányok } \\
\% \\
(95 \% \text { CI }) \\
\end{array}$ & $\begin{array}{l}\text { Fiúk } \\
\% \\
(95 \% \text { CI) } \\
\end{array}$ & $\begin{array}{l}\text { Nemek közti } \\
\text { különbségek } \\
p \text { érték* }\end{array}$ \\
\hline \multicolumn{5}{|c|}{ Besorolás (IOTF) } \\
\hline Túlsúlyos ${ }^{\#}$ & $\begin{array}{l}13 \\
(11,7 ; 14,5)\end{array}$ & $\begin{array}{l}13,6 \\
(11,6 ; 15,7)\end{array}$ & $\begin{array}{l}12,5 \\
(10,8 ; 14,5)\end{array}$ & 0,443 \\
\hline Elhízott & $\begin{array}{l}9,5 \\
(8,3 ; 10,7)\end{array}$ & $\begin{array}{l}10,1 \\
(8,4 ; 11,9)\end{array}$ & $\begin{array}{l}8,9 \\
(7,5 ; 10,5)\end{array}$ & 0,289 \\
\hline \multicolumn{5}{|c|}{ Besorolás (WHO) } \\
\hline Túlsúlyos ${ }^{\#}$ & $\begin{array}{l}14,8 \\
(13,4 ; 16,3)\end{array}$ & $\begin{array}{l}16,4 \\
(14,5 ; 18,5)\end{array}$ & $\begin{array}{l}13,3 \\
(11,3 ; 15,5)\end{array}$ & 0,037 \\
\hline Elhízott & $\begin{array}{l}13,6 \\
(12,1 ; 15,2)\end{array}$ & $\begin{array}{l}12,1 \\
(10,3 ; 14,3)\end{array}$ & $\begin{array}{l}15 \\
(13,1 ; 17,1)\end{array}$ & 0,028 \\
\hline \multicolumn{5}{|c|}{ Besorolás (magyar) } \\
\hline Túlsúlyos ${ }^{\#}$ & $\begin{array}{l}10,3 \\
(9,1 ; 11,6)\end{array}$ & $\begin{array}{l}9,9 \\
(8,3 ; 11,9)\end{array}$ & $\begin{array}{l}10,6 \\
(8,9 ; 12,5)\end{array}$ & 0,609 \\
\hline Elhízott & $\begin{array}{l}10,6 \\
(9,4 ; 11,9)\end{array}$ & $\begin{array}{l}11,3 \\
(9,5 ; 13,4)\end{array}$ & $\begin{array}{l}9,9 \\
(8,4 ; 11,6)\end{array}$ & 0,242 \\
\hline
\end{tabular}

* $p$ értékeket t próbával számoltuk folytonos változók és Pearson $\chi^{2}$ próbával kategórikus változók esetében

CI: konfidencia intervallum

\#A túlsúlyos kategória nem tartalmazza az elhízott eseteket

Saját szerkesztés

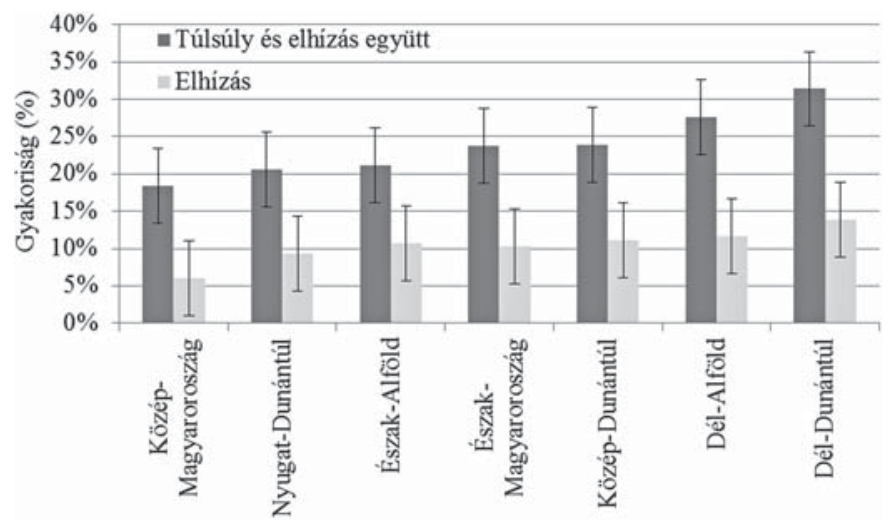

3. ábra. A túlsúly és elhízás együttes (sötét oszlopok), valamint az elhízás (világos oszlopok) előfordulásának régiós eloszlása 7 évesek körében 2016-ban.

Saját szerkesztés 
Összehasonlítva a 2010. és 2016. évi adatokat, úgy tűnik, hogy a hazánkban bevezetett szakma-politikai intézkedések hatására a túlsúly és az elhízás előfordulása stablizálódott, és kb. minden negyedik hétévest érinti (Kovács et al., 2018).

\section{MEGBESZÉLÉS}

Az elhízás kialakulásának hátterében kockázati tényezők bonyolult hálózata áll. Le kell szögezni, hogy a gyermekkori elhízás nem csupán a túlzott kalóriabevitel eredménye. A túlzott kalóriabevitel mindenképpen jelentős szerepet játszik, de ez egy rendkívül komplex, többtényezős betegség. A kockázati tényezők középpontjában az energia-egyensúly felbomlása áll, melyben legtöbbször kulcsszerepet játszik az inaktív életmód (túl sok tévénézés, számítógépes játékok) és az elégtelen fizikai aktivitás. Emellett azonban a túl rövid ideig tartó kizárólagos szoptatás (legalább hat hónap lenne az ideális), a hamar bevezetett csecsemőtápszerek, a magas születési súly (4 $\mathrm{kg}$ és e felett), a megváltozott anyagcsere és a genetikai hajlam is megjelenik.

Fontos kockázati tényező még a hátrányos társadalmi-gazdasági helyzet. Számos tanulmány támasztja alá, hogy az alacsonyabb iskolázottságúak körében magasabb a gyermekkori elhízás előfordulási aránya. Emellett a rosszabb gazdasági helyzetben lévő régióknál is magasabb az előfordulás. Magyarországon a Közép-magyarországi (6\%) és a Dél-dunántúli (12\%) régiók között kétszeres a különbség az elhízás előfordulásában.

A megelőzésnél fontos, hogy minél korábbi életkorban kezdődjön el, hiszen az étkezési és aktivitási szokások többsége az élet első pár évében alakul ki. Ezért a szülők, bölcsődék és óvodák szerepe kiemelkedő. Sajnos az élelmiszergyártók jelenlegi, gyermekeket célzó marketingstratégiája nem segíti a prevenciót. Emellett az urbanizáció, motorizáció és a mostanában kialakult új kulturális szokások is egyre kevésbé támogatják az egészséges életmódot.

\section{AZ OGYÉI GYERMEKKORI ELHÍZÁS VISSZASZORITTÁSÁT CÉLZÓ TEVÉKENYSÉGEI}

Az elmúlt tíz évben intézetünk, az Országos Gyógyszerészeti és Élelmezés-egészségügyi Intézet (OGYÉI) számos programot dolgozott ki az egyes kockázati tényezők előfordulásának csökkentésére. A HAPPY-hét 2010 óta rendszeresen meghirdetésre kerül. A program fő célja, hogy felhívja a vízfogyasztás fontosságára a figyelmet, a vízfogyasztás növelése, ezzel párhuzamosan a cukros, szénsavas üdítők fogyasztásának csökkentése által. Számos nemzetközi vizsgálat igazolta az elhízás és a cukros, szénsavas üdítők mértéktelen fogyasztása közötti összefüggést (Katzmarzyk et al., 2016). A programhoz csatlakozó iskolák/óvodák az eddigi 
évekhez hasonlóan az OGYÉI által rendelkezésükre bocsátott szakmai anyagok, programjavaslatok felhasználásával önállóan szervezik meg a HAPPY-hetet, maguk döntik el, hogy milyen foglalkozásokkal, játékokkal hívják fel a gyerekek figyelmét a vízfogyasztás fontosságára, illetve a cukros üdítők káros hatásaira.

2015. január 1-jén lépett hatályba az OGYÉI munkatársainak többéves előkészítő munkáját követően a közétkeztetésre vonatkozó táplálkozás-egészségügyi elöírásokról szóló 37/2014. (IV. 30.) EMMI rendelet, mely 2015. szeptember 1-töl alkalmazandó. Mivel a gyermekek idejük jelentős részét az óvodában, iskolában töltik, és a napi energiabevitelük 35-65\%-át itt fogyasztják, így a köznevelési intézmények kiemelt jelentőséggel bírnak az egészséges táplálkozás feltételeinek biztosításában és az egészséges életmód kialakításában. Ezen intézmények táplálkozás-egészségügyi környezetének javítása és egészségessé tétele ezért kulcsfontosságú az elhízás megelőzésében.

\section{IRODALOM}

Ágfalvi R. - Blatniczky L. - Darvay S. et al. (szerk.) (2004): Útmutató és táblázatok a gyermekkori tápláltság megitéléséhez. Országos Gyermekegészségügyi Intézet-Magyar Védőnők Egyesülete, http://www.futas.net/cikkek/fogyas/bmi-testtomeg-gyermekeknel-borredo-vastagsag-merese.pdf

Bridger, T. (2009): Childhood Obesity and Cardiovascular Disease. Paediatrics \& Child Health, 14, 3, 177-182. https://www.ncbi.nlm.nih.gov/pmc/articles/PMC2690549/

Cole, T. J. - Lobstein, T. (2012): Extended International (IOTF) Body Mass Index Cut-offs for Thinness, Overweight and Obesity. Pediatric Obesity, 7, 4, 284-294. DOI: 10.1111/j.20476310.2012.00064.x

Dietz, W. H. (2004): Overweight in Childhood and Adolescence. The New England Journal of Medicine, 350, 9, 855-857. DOI: 10.1056/NEJMp048008, https://www.researchgate.net/publication/7958089_Dietz_WH_Overweight_in_Childhood_and_Adolescence_N_Engl_J_ Med_350_855-857

Erdei G. - Bakacs M. - Illés É. et al. (2018): Substantial Variation across Geographic Regions in the Obesity Prevalence among 6-8 Years old Hungarian Children (COSI Hungary 2016). BMC Public Health, 18, 611. DOI: 10.1186/s12889-018-5530-6, https://bmcpublichealth.biomedcentral.com/articles/10.1186/s12889-018-5530-6

Joubert K. - Darvay S. - Gyenis Gy. et al. (2006): The National Longitudinal Child Growth Study: Results from Birth to 18 Years of Age. Budapest, Hungary: $83^{\text {rd }}$ Central Statistical Office Population Science Statistical Research Report

Katzmarzyk, P. T. - Broyles, S. T. - Champagne, C. M. et al. (2016): Relationship between Soft Drink Consumption and Obesity in 9-11 Years Old Children in a Multi-National Study. Nutrients, 8, 12, 770. DOI:10.3390/nu8120770, https://www.mdpi.com/2072-6643/8/12/770

Kovács V. A. - Bakacs M. - Kaposvári C. S. et al. (2018): Weight Status of 7-year-old Hungarian Children between 2010 and 2016 Using Different Classifications (COSI Hungary). Obesity Facts, 11, 3, 195-205. DOI: 10.1159/000487327, https:/www.karger.com/Article/FullText/ 487327 
de Onis, M. - Onyango, A. W. - Borghi, E. et al. (2007): Development of a WHO Growth Reference for School-aged Children and Adolescents. Bulletin World Health Organization, 85, 660-667. https://scielosp.org/scielo.php?script=sci_arttext\&pid=S0042-96862007000900010\& lng=en\&nrm=iso\&tlng=en

Sonntag, D. - Ali, S. - De Bock, F. (2016): Lifetime Indirect Cost of Childhood Overweight and Obesity: A Decision Analytic Model. Obesity (Silver Spring), 24, 1, 200-206. DOI: 10.1002/ oby.21323, https://onlinelibrary.wiley.com/doi/full/10.1002/oby.21323

Wijnhoven, T. M. - van Raaij, J. M. - Spinelli, A. et al. (2013): WHO European Childhood Obesity Surveillance Initiative 2008: Weight, Height and Body Mass Index in 6-9-year-old Children. Pediatric Obesity, 8, 79- 97. DOI: 10.1111/j.2047-6310.2012.00090.x

URL1: Word Health Organization: Facts and Figures on Childhood Obesity. http:/www.who.int/ end-childhood-obesity/facts/en/

URL2: Kyrou, I. - Randeva, H. S. - Tsigos, C. et al. (2018): Clinical Problems Caused by Obesity. In: Feingold, K. R. - Anawalt, B. - Beyonce, A. et al. (eds.): Endotext. South Dartmouth (MA): MDText.com, Inc. https://www.ncbi.nlm.nih.gov/books/NBK278973/

URL3: Word Health Organization: Why Does Childhood Overweight and Obesity Matter? http:// www.who.int/dietphysicalactivity/childhood_consequences/en/

URL4: World Health Organization: WHO Reference 2007. Growth Reference Data for 5-19 Years. http://www.who.int/growthref/en/ 